\title{
Litiasis múltiple de gran tamaño en neovejiga realizada hace 15 años
}

Ruiz Mondejar R, Donate Moreno MJ, Pastor Navarro H, Carrión López P, Gálvez Calderón J, Virseda Rodríguez JA.

Servicio de Urología. Complejo Hospitalario Universitario de Albacete.

Actas Urol Esp. 2007;31(7):803

$\mathrm{P}$ aciente de 75 años, diagnosticado de carcinoma vesical urotelial infiltrante hace 15 años. Se trato mediante cistectomía radical y reservorio urinario interno, con ileon destubulizado según la técnica de Melchior (Fig. 1). (UIV y Cistografía hace 15 años).

$\mathrm{El}$ paciente fue controlado en nuestro servicio durante los primeros cinco años desde la cirugía, desde entonces no acude a revisiones.

En fechas recientes acude al servicio de urgencias por cuadro clínico compatible con ITU complicada, que requiere su ingreso en el hospital.
En el estudio realizado se aprecia en radiografía simple de abdomen, tres imágenes compatibles con litiasis de gran tamaño, que teóricamente ocupan y moldean la neovejiga ileal (Fig. 2) confirmándose en la TAC (Fig. 3).

El paciente se programa para cirugía abierta y la extracción de las litiasis.

Correspondencia autor: Dr. R. Ruiz Mondéjar.

Servicio de Urología. Complejo Hospitalario Universitario de Albacete. Hermanos Falcó, 36 - 02006 Albacete Tel.: 967597235 E-mail: ruizmondejar@ono.com

Información artículo: Imágenes en Urología

Trabajo recibido: junio 2006

Trabajo aceptado: agosto 2006
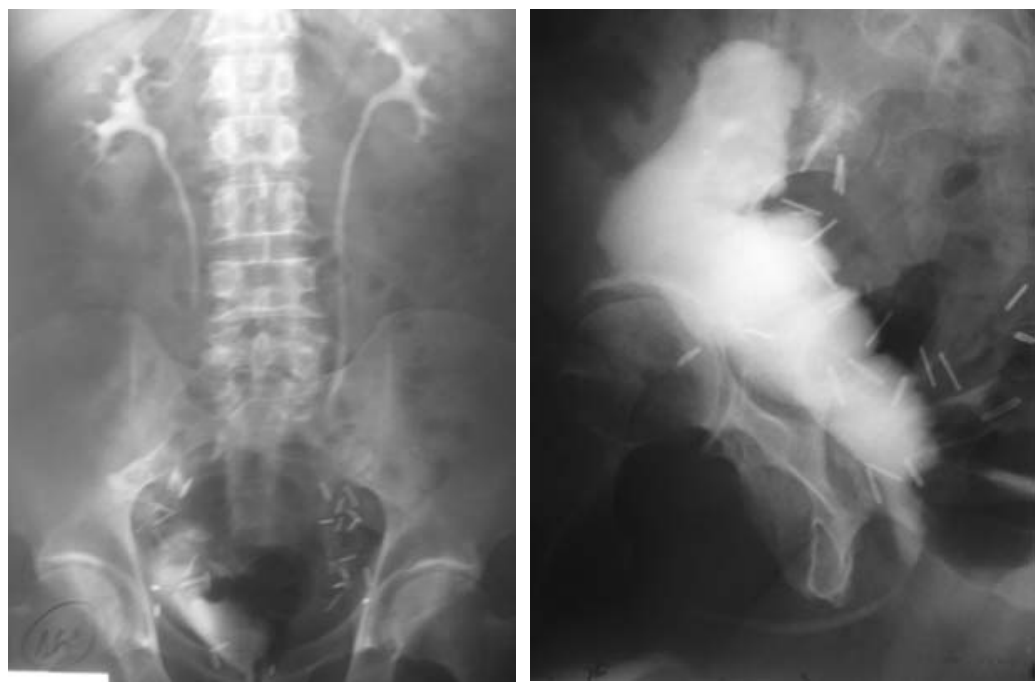

FIGURA 1. UIV y cistografia de neovejiga ileal hace 15 años.

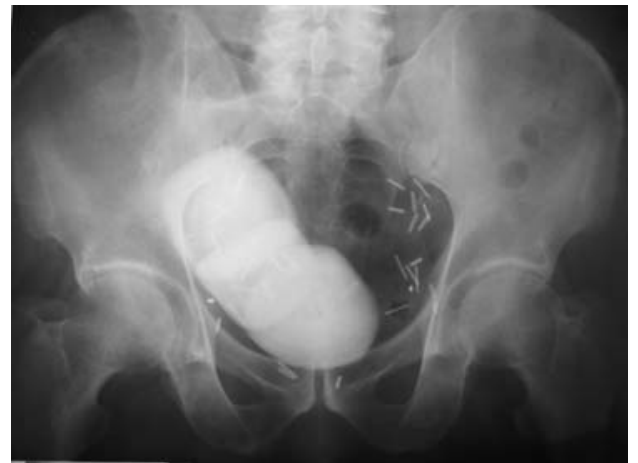

FIGURA 2. Radiografia simple de abdomen: litiasis de gran tamaño en pelvis.

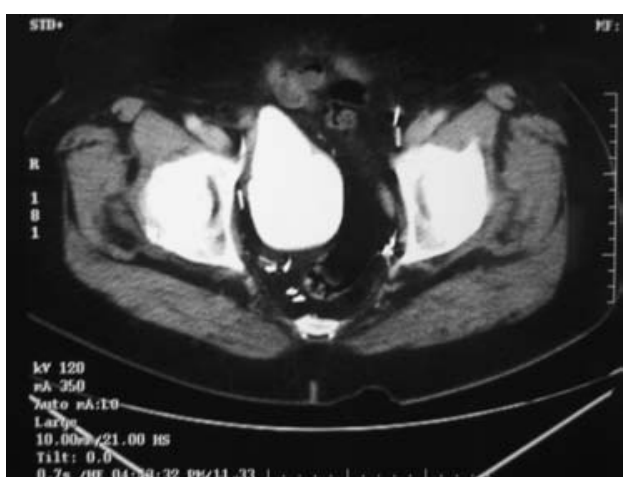

FIGURA 3. TAC :litiasis de gran tamaño dentro de la neovejiga ileal. 